УДК 531.7 .08

А. С. Дуднік ${ }^{1}$, к.т.н., доиент,

доиент кафедри мережевих та інтернет технологій

В. П. Квасніков ${ }^{2}$, д.т.н., професор,

завідувач кафедри комп'ютеризованих електротехнічних систем та технологій

${ }^{1}$ Київський національний університет ім. Т. Шевченка

вул. Ванди Василевської, 24, Київ, 03056, Україна

${ }^{2}$ Національний авіаційний університет

пр. Космонавта Комарова 1, м. Київ-58, 03058, Україна

\title{
АНАЛІТИЧНА МОДЕЛЬ ВИМІРЮВАННЯ ВІДСТАНІ ЗА ДОПОМОГОЮ СЕНСОРНИХ МЕРЕЖ ТА ОЦІНКА ПОХИБКИ ВИМІРЮВАННЯ
}

В даній статті досліджується задача визначення відстані між прийомопередавачами хаотичних радіоімпульсів. розрахунок відстані виробляється за часом поширення сигналу в ефірі. Очінюється точність визначення між прийомопередавачами на основі часу проходження сигналу, з урахуванням перешкод.

Ключові слова: прийомопередавач, сенсор, радіоімпульс, час, відстань, похибка вимірювання.

Актуальність. Зараз існують різні технологічні рішення для визначення положення об’єктів в просторі або на поверхні землі. Це пов'язано 3 тим, що неможливо реалізувати один універсальний спосіб, що підходить для всіх можливих випадків. Точніше кажучи, неможливо зробити пристрій, технічні характеристики якого відповідали б вимогам всіх (або навіть більшості) задач.

Аналіз останніх джерел. Існують технології позиціонування, такі як GPS, про які йдеться у роботі Sichitiu M. [1], Galileo , якому присвячена робота Федерації американських науковців [2], Глонасс, про яку йдеться у спільній роботі іспанських вчених про моніторинг навколишнього середовища [3], застосовують Wi-Fi [4] або ультракороткі імпульси, про що йдеться у відповідному стандарті Інститут інженерів електротехніки та електроніки, або технології позиціонування стільникових телефонів GSM, якому присвячена робота Не Т. [5] і т.д. У всіх цих технологій існують свої плюси і мінуси. Galileo, ГЛОHACC, GPS наприклад, дозволяють орієнтуватися на поверхні землі, маючи при собі компактний пристрій 3 набором карт місцевості. Це дуже корисні технології для переміщення на відкритій місцевості. Точність положення таких пристроїв зараз досягає одиниць метрів. Однак вона може погіршитися в великих містах, в умовах складного рельєфу місцевості або просто в закритому приміщенні. В останньому випадку застосування супутникового позиціонування неприйнятне.
Метою даної статті є опис моделі визначення часу прийняття сигналу 3 метою визначення відстані між сенсорними прийомопередавачами хаотичних радіоімпульсів, а також оцінка похибки вимірювань.

Розрахунок відстані здійснюється відносно часу поширення сигналу в ефipi, а також обов'язково оцінюється точність визначення відстані.

Постановка задачі. Задача позиціонування викликає великий інтерес у розробників і виробників обладнання, що може свідчити про її попит. Причому більшість рішень використовують в якості носія інформації радіосигнал. Отже, універсальні пристрої, що дозволяють одночасно передавати і приймати дані, а також визначати своє положення в просторі, матимуть споживчу цінність. Один зі стандартів, що регламентує роботу безпровідних радіопередавальних пристроїв 3 функцією позиціонування - IEEE 802.15.4.

Загальний підхід до визначення місця розташування об'єкта заснований на вимірюванні характеристик радіосигналу, який випромінюється передавачем, розташованим на об’єкті, і приймається стаціонарними приймачами з відомими координатами [6]. За цими характеристиками оцінюється відстань між передавачем і кожним 3 приймачів. Потім 3 урахуванням геометричних принципів визначаються координати об’ єкта.

В якості характеристик сигналу можуть бути використані наступні величини: 
- час поширення сигналу від передавача до приймача;

- різниця показників часу поширення сигналів від передавача до різних приймачів;

- інтенсивність сигналу;

- напрямок приходу сигналу.

Опис моделі визначення відстані

Для визначення відстані між двома об'єктами може бути використано також час поширення сигналу від першого об'єкта до другого плюс час поширення сигналу в зворотному напрямку.

Розглянемо задачу визначення відстані між передавачем і приймачем за допомогою хаотичних радіоімпульсів.

Будемо вважати, що є 2 пристрої: зондуючий (А) і зондований (Б). Обидва пристрої включають в себе приймач, передавач і цифрову частину. Передавач в А випромінює імпульс або серію імпульсів, а приймач в Б, відповідно, приймає імпульс або серію імпульсів. Через фіксовану тимчасову затримку передавач в Б випромінює одиночний імпульс або пачку імпульсів, а приймач в А їх приймає. Інтервал часу $\Delta t$ між моментом випромінювання імпульсу передавачем в А і моментом його приходу в приймач в $\mathrm{A}$, за вирахуванням затримки $\tau$ в пристрої Б, поділений навпіл і помножений на швидкість світла $c$, визначає відстань $l$ між передавачем і приймачем:

$$
l=\frac{\Delta t-\tau}{2} c .
$$

Момент приходу хаотичного радіоімпульсу будемо оцінювати, використовуючи приймач, який виділяє огинаючу хаотичного радіоімпульсу. Приймач являє собою послідовно з'єднані квадратичний детектор і фільтр нижніх частот. Після фільтра нижніх частот розташовується граничний пристрій, що фіксує момент часу, коли сигнал, відповідний імпульсу, починає перевищувати деяке порогове значення (рис. 1). Цей момент часу приймаємо за момент приходу хаотичного радіоімпульсу.

\section{Оцінка похибки вимірювання часу \\ з метою визначення відстані між \\ об'єктами, з урахуванням перешкод}

Оцінимо похибку у визначенні моменту часу приходу переднього фронту імпульсу, викликану тепловим шумом, а також ефектом неоднорідності розподілу енергії в часі протягом усього імпульсу. Скористаємося прикладом 3 [7] (див. рис. 1). В даному випадку, оскільки використовується огинаюча радіоімпульсу на виході приймача, то немає значення, який несучий сигнал мав радіоімпульс, а важлива тільки рівномірність розподілу енергії в часі, відповідно тривалості всього імпульсу [8]. На малюнку суцільною лінією зображена огинаюча незашумленого імпульсу, пунктирною - імпульсу з шумом. Горизонтальною пунктирною лінією вказано поріг компаратора.

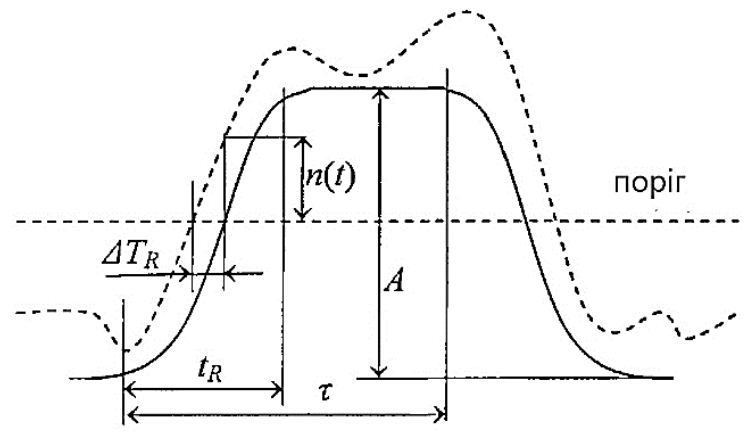

Рис. 1. Визначення часу приходу імпульсу по передньому фронту

Нехай $n(t)$ - зміщення імпульсу через шум за амплітудою, $A$ - амплітуда прийнятого незашумленого імпульсу, $\Delta T_{R}$ - похибка вимірювання часу приходу імпульсу, $t_{R}$ - тривалість переднього фронту імпульсу, $\tau$ - тривалість імпульсу при передачі. Тоді швидкість росту переднього фронту імпульсів [9] в незашумленому $S_{1}$ i зашумленому $S_{2}$ випадках буде відповідно [10]:

$$
\begin{gathered}
S_{1}=\frac{A}{t_{R}} \\
S_{2}=\frac{n(t)}{\Delta T_{R}}
\end{gathered}
$$

При великих амплітудах імпульсів ці швидкості росту повинні бути рівні. Тобто $S_{1}=S_{2}$. Тоді з (2) і (3)

$$
\begin{gathered}
\Delta T_{R}=\frac{n(t)}{A / t_{R}} \text {, або } \\
\sqrt{\overline{\left(\Delta T_{R}\right)^{2}}}=\delta T_{R}=\frac{t_{R}}{\sqrt{\frac{A^{2}}{n^{2}}}}=\frac{t_{R}}{\sqrt{\frac{2 P}{N}}}
\end{gathered}
$$

де $\frac{A^{2}}{n^{2}}$ відношення сигнал/шум для продетектованого відеоімпульсу. Тут $P$ - потужність сигналу, $N$ - потужність шуму в смузі фільтру низьких частот (ФНЧ). Якщо $B$ - смуга ФНЧ то

Нехай

$$
t_{R}=\frac{1}{B}
$$

$$
S=\frac{E}{\tau},
$$


$N=N_{0} B$, де $E-$ енергія імпульсу, що приймається, $N_{0}$ - спектральна густина потужності шуму. Тоді

$$
\delta T_{R}=\frac{\tau}{\sqrt{2 B \frac{E}{N_{0}}}}
$$

Таким чином, якщо, наприклад, полоса $B=5 \times 10^{7}$ Гц, $\tau=10^{-7} \mathrm{c}, \frac{E}{N_{0}}=20$ дБ $=100$, [11] то $\delta T_{R} \approx 3$ нс. Вплив ефекту неоднорідності розподілу енергії в хаотичному імпульсі за часом схожий 3 впливом білого гаусового шуму. Тому, оцінивши співвідношення «сигнал/шум», викликане цим ефектом, можна порівняти його зі співвідношенням сигнал/шум, що викликане білим шумом, і підставляти в розрахунки менше 3 цих двох відношень.

Висновки. Побудовано аналітичну модель визначання відстані між сенсорними прийомопередавачами на основі часу прибуття сигналу.

Проведено оцінку похибки часу прибуття сигналу, а також визначено основні параметри, що на неї впливають.

В подальших дослідженнях, для можливості отримання альтернативних результатів, a також більш детального аналізу похибки вимірювань, до складу сенсорної мережі буде включено лазерні віддалеміри.

\section{Список літератури}

1. Sichitiu M., Ramadurai V. Localization of wireless sensor networks with a mobile beacon. In Proceedings of the 6st IEEE International Conference on Mobile Ad Hoc and Sensor Systems (MASS 2014), FL, October 2014. P. 174-183.

2. Sound Surveillance System (SOSUS). URL: http://www.fas.org/irp/program/collect/sosus. htm. Federation of American Scientists.

3. SISVIA (SIstema de Seguimiento y VIgilancia Ambiental). URL: http://www.dimap.es/news.html. Technology and environment.

4. Institute of Electrical and Electronics Engineers / Inc., IEEE Std. 802.15.4-2015, IEEE Standard for Information Technology - telecommunications and Information Exchange between Systems - Local and Metropolitan Area Networks - Specific Requirements Part 15.4: Wireless Medium Access Control (MAC) and Physical Layer (PHY) Specifications for Low Rate Wireless Personal Area
Networks (WPANs). New York: IEEE Press. 2015. P. 250.

5. He T., Huang C., Blum B. Range-free localization schemes for large scale sensor networks. In MobiCom '09: Proceedings of the 9th Annual International Conference on Mobile Computing and Networking. New York, 2016, ACM Press, New York. P. 81-95.

6. Derivation of Friis Transmission Formula URL: http://www.antenna-theory.com/basics /friis.php. The Friis Equation - Назва $з$ титул. екрану.

7. Savvides A., Han C. Strivastava M. Dynamic fine-grained localization in ad-hoc networks of sensors. In 14th ACM/IEEE International Conference on Mobile Computing and Networking. Rome, Italy, 2017. P. 166-179.

8. Hofmann-Wellenho B., Lichtenegger H., Collins J. Global Positioning System: Theory and Practice, 15th edition // Springer-Verlag. Berlin. 2014.

9. Elson J. Time synchronization in wireless sensor networks // Department Computer Sciences, University of California, Ph.D. dissertation, Los Angeles. 2014.

10. Whitehouse K. The design of calamari: An ad hoc localization system for sensor networks. M.S. thesis, University of California at Berkeley. 2015.

11.Priyantha N., Balakrishnan H., Teller. S. The cricket compass for context aware mobile applications. In 17th ACM International Conference on Mobile Computing and Networking. Rome, Italy. July 2016. P. 325.

\section{References}

1. Sichitiu, M., Ramadurai, V. (2014). Localization of wireless sensor networks with a mobile beacon. In the Proceedings of the 6st IEEE International Conference on Mobile Ad Hoc and Sensor Systems (MASS 2014). Filadelfia, pp 174-183 [in USA].

2. Federation of American Scientists (2016). Sound Surveillance System (SOSUS). [in USA].

3. SISVIA (SIstema de Seguimiento y VIgilancia Ambiental) (2016). [in Spain].

4. Institute of Electrical and Electronics Engineers (2015). IEEE Std. 802.15.4- 2015, IEEE Standard for Information Technology - telecommunications and Information Exchange between Systems - Local and Metropolitan Area Networks - Specific Requirements Part 15.4: Wireless Medium Access Control 
(MAC) and Physical Layer (PHY) Specifications for Low Rate Wireless Personal Area Networks (WPANs). IEEE Press. P. 250 [in USA].

5. He, T., Huang, C., Blum, B. (2016). Rangefree localization schemes for large scale sensor networks. In: the MobiCom '09: Proceedings of the 9th Annual International Conference on Mobile Computing and Networking (ACM 2016). New York. Pp. 81-95. [in USA].

6. Derivation of Friis Transmission Formula (2016). [in USA].

7. Savvides, A., Han, C. Strivastava, M. (2016). Dynamic fine-grained localization in ad-hoc networks of sensors. In: the 14th ACM/IEEE International Conference on Mobile Computing and Networking (ACM 2016). Rome, pp. 166-179 [in Italy].
8. Hofmann-Wellenho B., Lichtenegger H., Collins J. (2014). Global Positioning System: Theory and Practice, 15th edition. SpringerVerlag, Berlin. [in Germany].

9. Elson, J. (2014). Time synchronization in wireless sensor networks. Department Computer Sciences, University of California (Ph.D. dissertation), Los Angeles, (in USA).

10. Whitehouse K. (2015). An ad hoc localization system for sensor networks. M.S. thesis, University of California at Berkeley. Berkeley. [in USA].

11.Priyantha, N., $\quad$ Balakrishnan, H., $\quad$ Teller, S. (2016). The cricket compass for context aware mobile applications. In: the 17th ACM International Conference on Mobile Computing and Networking (ACM 2016). Rome. P. 2016 [in Italy].

\author{
A. S. Dudnik ${ }^{1}$, Ph.D., associate professor \\ Associate Professor of the Department of Network and Internet Technologies \\ V. P. Kvasnikov², Doctor of Technical Sciences, Professor \\ Head of the Department of Computerized Electrical Systems and Technologies \\ ${ }^{1}$ Kiev National University named after. T. Shevchenko \\ street Vandy Vasilevskaya, 24, Kyiv, 03056, Ukraine \\ ${ }^{2}$ National Aviation University \\ Ave Cosmonaut Komarova 1, Kyiv-58, 03058, Ukraine
}

\title{
ANALYTICAL MODEL OF MEASUREMENT AGAINST SENSOR NETWORKS AND EVALUATION OF MEASUREMENT ERROR
}

Now there are various technological solutions for determining the position of objects in space or on the surface of the earth. This is due to the fact that it is impossible to implement one universal method that is suitable for all possible cases. More precisely, it is impossible to make a device whose specifications would meet the requirements of all (or even most) tasks. The task of positioning is of great interest to developers and manufacturers of equipment, which can testify to its demand. Moreover, most solutions use the radio signal as a carrier of information. Consequently, universal devices that allow simultaneously to transmit and receive data, as well as determine their position in space will have a consumer value. One of the standards governing the operation of wireless transmitting devices with positioning function - IEEE 802.15.4. The general approach to determining the location of an object is based on measuring the characteristics of the radio signal emitted by the transmitter located on the object, and is taken by stationary receivers with known coordinates. According to these characteristics, the distance between the transmitter and each of the receivers is estimated. Then, taking into account the geometric principles, the coordinates of the object are determined. In this paper, the problem of determining the distance between transceivers of chaotic radio pulses is investigated. the distance calculation is based on the propagation of the signal on the air. It is estimated the accuracy of the definition between the transceivers, based on the time of the signal passing, taking into account the obstacles. In further studies, for the possibility of obtaining alternative results, as well as a more detailed analysis of the measurement error, the laser distance measurement will be included in the sensor network.

Keywords: transceiver, sensor, radio pulse, time, distance, error measurement.

Стаття надійшла 05.06.2018.

Статтю представляс В. П. Квасніков, д.т.н., професор. 